\title{
Experimental analysis of energy performance of a ventilated window for heat recovery under controlled conditions
}

\author{
Appelfeld, David; Svendsen, Svend
}

Published in:

Energy and Buildings

Link to article, DOI:

10.1016/j.enbuild.2011.08.018

Publication date:

2011

Document Version

Publisher's PDF, also known as Version of record

Link back to DTU Orbit

Citation (APA):

Appelfeld, D., \& Svendsen, S. (2011). Experimental analysis of energy performance of a ventilated window for heat recovery under controlled conditions. Energy and Buildings, 43(11), 3200-3207.

https://doi.org/10.1016/j.enbuild.2011.08.018

\section{General rights}

Copyright and moral rights for the publications made accessible in the public portal are retained by the authors and/or other copyright owners and it is a condition of accessing publications that users recognise and abide by the legal requirements associated with these rights.

- Users may download and print one copy of any publication from the public portal for the purpose of private study or research.

- You may not further distribute the material or use it for any profit-making activity or commercial gain

- You may freely distribute the URL identifying the publication in the public portal

If you believe that this document breaches copyright please contact us providing details, and we will remove access to the work immediately and investigate your claim 
Erratum

\section{Erratum to "Experimental analysis of energy performance of a ventilated window for heat recovery under controlled conditions" [Energy and Buildings 43 (11) (2011) 3200-3207]}

\section{David Appelfeld*, Svend Svendsen}

Department of Civil Engineering, Technical University of Denmark, Brovej, Building 118 DK-2800 Kgs. Lyngby, Denmark

The publisher regrets the mistake in the title. It should be "Experimental analysis of energy performance of a ventilated window for heat recovery under controlled conditions" instead of "Experimental analysis of energy performance f a ventilated window for heat recovery under controlled conditions."

The publisher would like to apologise for any inconvenience caused. 